\title{
A large array of inselbergs on a continuation of the sub-Cambrian peneplain in the Baltic Basin: evidence from seismic data, Western Lithuania
}

\author{
Milda GRENDAITÉ丶 ${ }^{1, *}$, Dainius MICHELEVIČIUS ${ }^{1,2}$ and Sigitas RADZEVIČIUS ${ }^{1}$ \\ 1 Vilnius University, Faculty of Chemistry and Geosciences, Institute of Geosciences, M.K. Čiurlionio str. 21/27, 03101 \\ Vilnius, Lithuania \\ 2 Geobaltic UAB, Skrobly str. 27, 03140 Vilnius, Lithuania
}

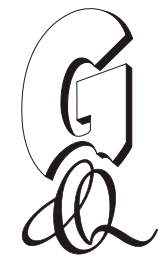

\begin{abstract}
Grendaitè, M., Michelevičius, D., Radzevičius, S., 2022. A large array of inselbergs on a continuation of the sub-Cambrian peneplain in the Baltic Basin: evidence from seismic data, Western Lithuania. Geological Quarterly, 66: 2, doi:
\end{abstract} 10.7306/gq.1633

Associate Editor: Piotr Krzywiec

The sub-Cambrian peneplain is well-known in Scandinavia, outcropping in Finland, Sweden and Norway. This peneplain is thought to have formed within the Baltic Sea region in Cryogenian and Ediacaran/early Cambrian time, when Baltica, a part of Rodinia for most of that time, experienced tectonic stability, strong sheet-wash weathering and glaciations. While the peneplain outcrops in the Baltic Shield region, it continues beneath Phanerozoic strata of the Baltic Basin. This buried part of the sub-Cambrian peneplain is known to have several isolated inselbergs. We interpret newly acquired 2D and 3D seismic data and show that the sub-Cambrian peneplain extends at least to Western Lithuania where the palaeotopography of the Precambrian basement changes its character from peneplain-like flat to hilly terrain with a large array of inselbergs. Even though some of the largest features of this palaeotopography have been known before, they are here demonstrated for the first time within the regional context of the sub-Cambrian peneplain.

Key words: sub-Cambrian peneplain, seismic data interpretation, Western Lithuania, saprolite, weathering crust, inselberg.

\section{INTRODUCTION}

A surface formed by sub-aerial or fluvial erosion and is worn down to near base level (thus, is at the last stage of erosion), is termed a peneplain (Phillips, 2002). Such a surface has low relief, its different lithologies being worn down to the same level, and is typically of sub-continental extent. Three peneplain surfaces are identified within Scandinavia: sub-Cambrian, sub-Cretaceous, and Tertiary (Lidmar-Bergström, 1995; Lidmar-Bergström et al., 2017). The oldest of these, the sub-Cambrian peneplain (Fig. 1A) formed within the Baltic Sea region during the Cryogenian and Ediacaran/Cambrian (Lidmar-Bergström, 1995), in response to prolonged tectonic stability and climate conditions that favoured weathering (Phillips, 2002). The Cryogenian glaciations contributed to the formation of this flat surface (Keller et al., 2019; Paszkowski et al., 2019), but were not the only factor in its formation (Lidmar-Bergström, 1995). Moreover, glaciations do not necessarily affect the major landforms (Bonow, 2003; Lidmar-Berg-

\footnotetext{
* Corresponding author, e-mail: milda.grendaite@chgf.vu.lt
}

Received: August 4, 2021; accepted: November 30, 2021; first published online: January 31,2022 ström and Olvmo, 2015). However, glaciations do not only shape the surface by eroding rock but also create a range of glacial landforms such as drumlins, moraines, subglacial meltwater channels and mega-scale glacial lineations (Dowdeswell et al. 2016). The sub-Cambrian peneplain is directly related to the globally traced "Great Unconformity" which represents a long period of continental denudation in the Neoproterozoic (Peters and Gaines, 2012), when Baltica was a part of Rodinia (Li et al., 2008; Poprawa et al., 2020).

The sub-Cambrian peneplain is thought to have been extremely flat with only $20 \mathrm{~m}$ variation in height (Lidmar-Bergström, 1995). Currently, the original surface of peneplain is no longer flat. Rather, it is found in various settings that differ from the original (here, most examples are taken from Southern Scandinavia). In Western Norway, the peneplain's surface is flexed westwards beneath the load of Caledonian nappes (Gabrielsen et al., 2015). In Finland, Sweden, and Norway it is found in outcrops where it has been re-exposed after Paleozoic strata have been removed (Lidmar-Bergström, 1995; Gabrielsen et al., 2015). In addition, some of the present-day Swedish landscape types - such as plains with residual hills and undulating hilly relief - are directly derived (re-worked) from the sub-Cambrian peneplain re-exposed during the Mesozoic and Cenozoic (Lidmar-Bergström, 1995; Lidmar-Bergström and Olvmo, 2015; Lidmar-Bergström et al., 2017). Interestingly, the peneplain's surface is found even in uplifted areas such as 
the South Swedish Dome (Lidmar-Bergström et al., 2017) and the Hardanger plateau in Southern Norway, the latter is $>1000 \mathrm{~m}$ above mean sea level (Jarsve et al., 2014; Japsen et al., 2018) and has survived glaciations (Bonow et al., 2003). Eastwards, the peneplain's surface dips under the Baltic Basin (Lidmar-Bergström, 1993, 1995; Lidmar-Bergström et al., 2013,
2017). Since the original surface of the sub-Cambrian peneplain was almost flat, it can be used as a reference surface and help interpret subsequent tectonic events (Lidmar-Bergström et al., 2013; Gabrielsen et al., 2015) and erosional processes (Lidmar-Bergström, 1993, 1995; Lidmar-Bergström et al., 2017).

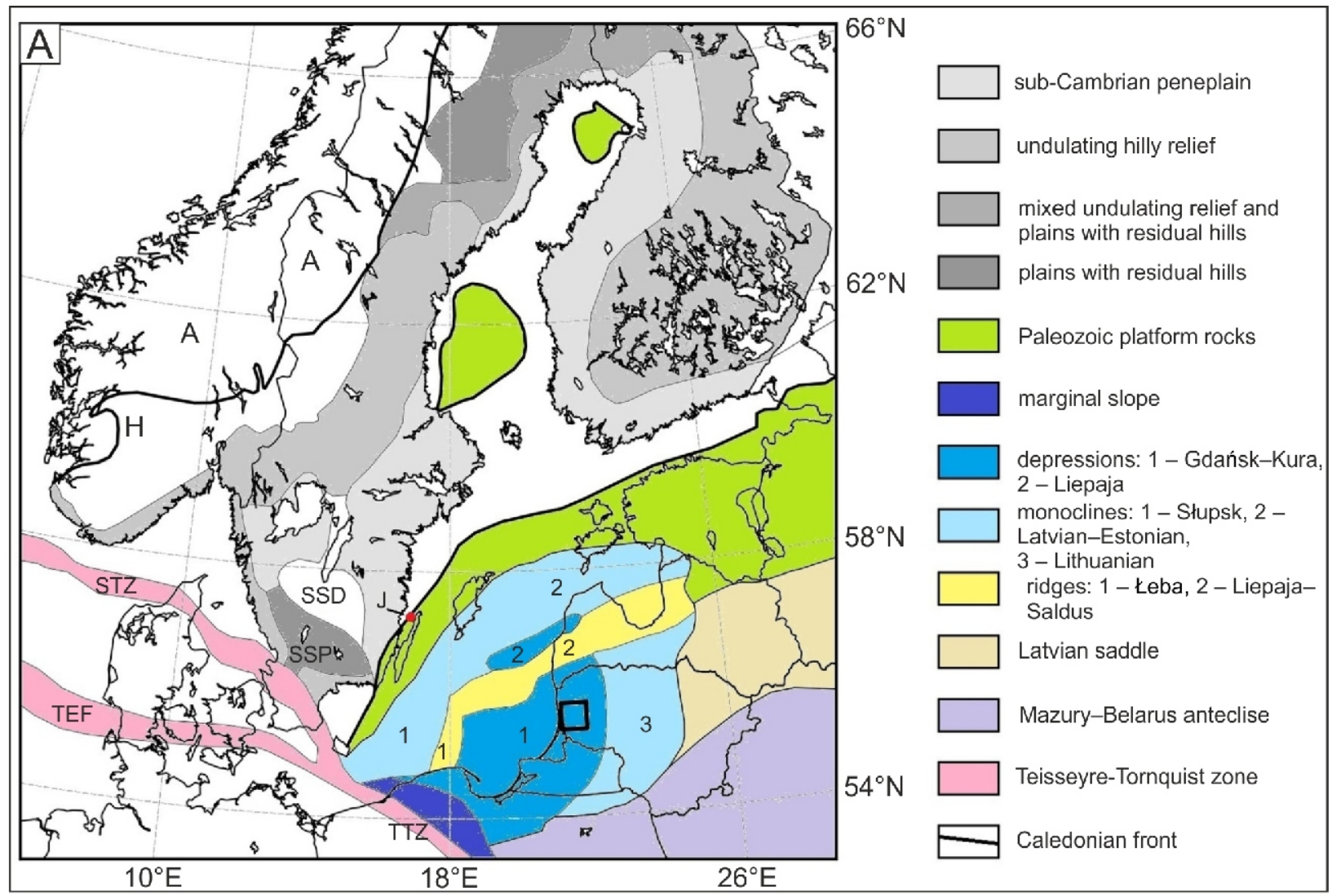

B

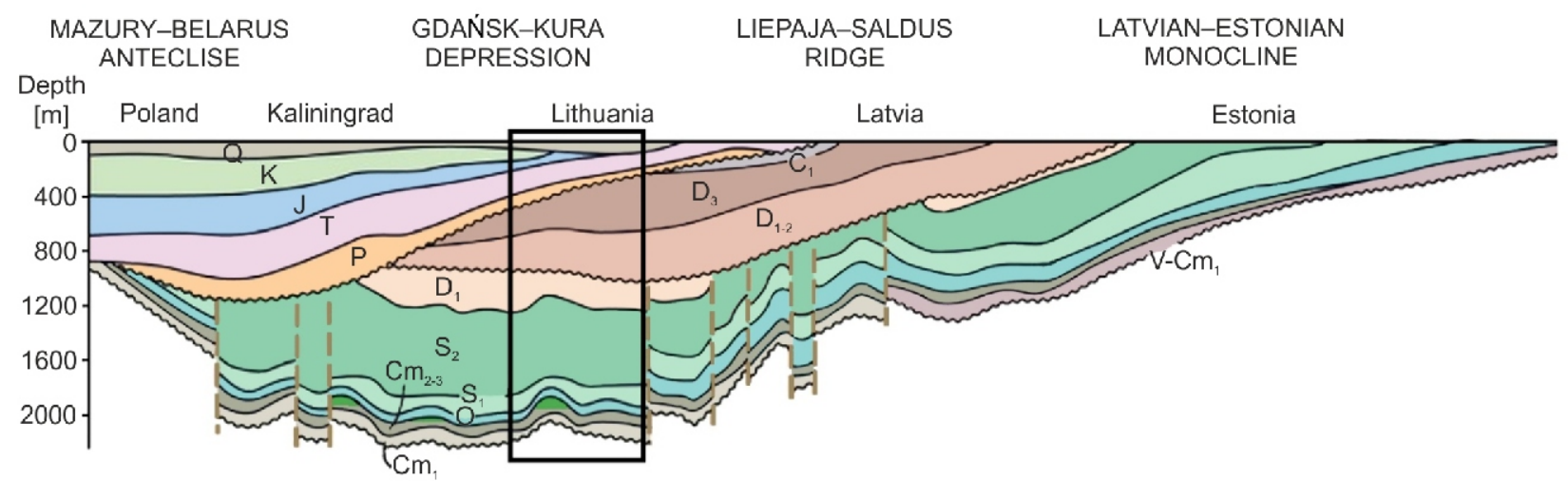

Fig. 1A - location of study area in Western Lithuania (black thick rectangle) within both the Baltic Basin and Baltic Sea region; B - schematic regional N-S geological profile of the Baltic Basin and the position of our study area in Western Lithuania (black thick rectangle)

A - sub-Cambrian peneplain is exposed in the Baltic Shield between the Caledonian front (edge of Caledonian allochthon) and edge of Paleozoic cover rocks (East European Platform). Sub-Cambrian peneplain and relief types related to it are shown in grey. SSD - South Swedish Dome, H - Hardanger plateau, J - Jungfrun. The Baltic Basin and its structural units are shown in blue (monoclines, depressions, slopes) and yellow (ridges); numbers are explained in the legend. Baltic Basin, Latvian Saddle, Mazury-Belarus anteclise (rise) and Southern Slope of the Baltic Shield beneath Paleozoic cover) are structural units of the East European Platform. Teisseyre-Tornquist Zone (TTZ) separates the East European Craton in the northeast from Phanerozoic Europe in the south-west, and splits into the Sorgenfrei-Teisseyre Zone (STZ) and Trans-European Fault (TEF). Mesozoic and Cenozoic sedimentary cover is not shown in order to show the Baltic Basin (after Brangulis et al., 1993; Thybo, 2000; Lidmar-Bergström et al., 2013; Jarsve et at., 2014; Gabrielsen et al., 2015). B - geological systems are marked by the appropriate letters (after Dadlez et al., 2007) 
Though peneplains are flat by definition, features like "inselbergs" - sporadic and isolated rocky hills and clusters of hills - can be encountered, often adjacent to plateaus or highlands. These residual hills either rise above the peneplain - like Jungfrun in Sweden (Lidmar-Bergström, 1993, 1995) - or only the tops of the residual hills are a part of peneplain (residual peneplain) while at their base the peneplain has been eroded away (Lidmar-Bergström, 1988; Lidmar-Bergström and Olvmo, 2015; Nenonen et al., 2018). Inselbergs like Jungfrun appear to be uncommon within the sub-Cambrian peneplain while residual hills occur near its erosional limits. Isolated sporadic hill-like features of crystalline basement are reported within the Baltic Basin (Stirpeika, 1999; Modliński et al., 1999; Brangulis and Kanevs, 2002; Sopher et al., 2016; Estonian Land Board, Geological Survey of Estonia, 2020; Ani and Meidla, 2020).

Saprolite, a weathered surface of bedrock, is characteristic of peneplains (Migoń and Lidmar-Bergström, 2002). The saprolite of the sub-Cambrian peneplain is relatively thin; sheet-wash and a lack of vegetation are thought to have prevented the formation of thick saprolite (Lidmar-Bergström, 1993; Lidmar-Bergström et al., 2013). Kaolinitic saprolite, associated with the sub-Cambrian peneplain, is found in Sweden (Lidmar-Bergström et al., 1997). In Estonia, the crystalline basement is found in boreholes at depths of $0.1-0.8 \mathrm{~km}$, and its top few tens of metres are affected by weathering (Soesoo et al., 2004). This weathered layer ("the Baltic palaeosol") can be divided into three parts based on the degree of alteration (Liivamägi et al., 2014). In the Kaliningrad District (Russia), the crystalline basement is found in boreholes at a depth of $\sim 2.5 \mathrm{~km}$ and its surface can be divided into weathering crust and substrate, which in turn is divided into upper and lower parts (Meshcherskii et al., 2003). These last observations essentially describe saprolite, a product of deep chemical weathering (Butt et al., 2000), where the lowest layer is the least affected by weathering and contains weathering fractures, the middle layer has altered minerals, but the structure of the original rock can be recognized, and the upper layer is unrecognizable loose material with kaolinitic clay. In Western Lithuania, the crystalline basement is found in boreholes beneath the $\sim 2 \mathrm{~km}$ thick platform cover and is often described as weathered, strongly weathered, or having a weathering crust which is a few meters thick; kaolinitization is also encountered. The weathering crust of the Lithuanian crystalline basement has not been studied recently (Vasilyev, 1969).

Where the sub-Cambrian peneplain is not exposed, it is overlain by rocks of different ages - from Ediacaran (Vendian) to Early Ordovician - and so the upper stratigraphic limit of the formation of the sub-Cambrian peneplain is diachronous within the Baltic Sea region. Hence, the peneplain is called sub-Cambrian. Large parts of Baltica were subject to transgression in the early Cambrian as a result of the global eustatic sea level rise (Cocks and Torsvik, 2005), and terrigenous sediments were deposited in the shallow Cambrian sea (Nielsen and Schovsbo, 2011). The weathering products of the sub-Cambrian peneplain are related to the origin of terrigenous Cambrian deposits, but the sedimentary provenance is not well studied (Konsa and Puura, 1999; Lorentzen et al., 2018). The preservation of the original surface of the sub-Cambrian peneplain in Scandinavia is exceptional and was possible due to the presence of a Paleozoic sedimentary cover, which was first removed not earlier than the Carboniferous or even the Pliocene (Elvhage and Lidmar-Bergström, 1987; Lidmar-Bergström et al., 2017). The peneplain is known to have been re-exposed in the Mesozoic and Cenozoic in some parts of Scandinavia. South and east off the Swedish coast, the Paleozoic sedimentary cover still remains today and is a part of the Baltic Basin. Therefore, the original surface of the sub-Cambrian peneplain is supposed to continue eastwards off Sweden and be well preserved beneath the strata of the Baltic Basin. This study analyses the newly acquired seismic data in search of the sub-Cambrian peneplain in Western Lithuania (see Fig. 1A).

\section{GEOLOGICAL BACKGROUND}

The crust and crystalline basement of Western Lithuania formed in the Paleoproterozoic during the Svecofennian orogeny and is older than $1.8 \mathrm{Ga}$ (Claesson et al., 2001; Motuza et al., 2008; Bogdanova et al., 2015). Mesoproterozoic magmatism is present in Western Lithuania (Motuza et al., 2006) as well as in Northern Poland and Western Latvia (Dörr et al., 2002). The Jotnian strata, also attributed to the Mesoproterozoic, are the oldest non-metamorphosed sedimentary rocks within the Baltic Sea region. They occur patchily and do not cover the entire Baltic Sea region (Lundmark and Lamminen, 2016). In Western Lithuania, the Jotnian strata are found in a few boreholes only and have a maximum thickness of $20 \mathrm{~m}$ (Stirpeika, 1999). The southwestern part of the East European Craton (a part of the Baltic Sea region) is overlain by sedimentary rocks of the Baltic Basin (Fig. 1A). In Western Lithuania, the Phanerozoic succession is represented by the Cambrian-Cretaceous and Quaternary (Fig. 1B).

The basin's sedimentary fill is traditionally divided into separate stratigraphic units that have different spatial development and that are separated by stratigraphic unconformities, which in turn are major reference surfaces for basin-wide interpretation. The Ediacaran-lower Cambrian succession is relatively thin, and is mostly present in the northeastern part of the Baltic Basin, and not present in Western Lithuania. The Caledonian succession (lower Cambrian-Lower Devonian, Lochkovian) is the most widespread, the thickest (2-4 km in the deepest parts of the basin; thickens towards the Teisseyre-Tornquist Zone), and the most affected by compression related to the Caledonian orogeny (Sopher et al., 2016). The main structural units of the Baltic Basin are defined by Caledonian structures (Brangulis et al., 1993). The Caledonian succession comprises Cambrian clastic rocks, Ordovician and Silurian carbonates and clayey deposits, and Lower Devonian clastic rocks and lagoonal deposits (Paškevičius, 1997). This succession belongs to the Baltic Basin, which began to develop in the late Ediacaran-early Cambrian in relation to Baltica's break-up from Rodinia. The rate of subsidence increased in the late Ordovician-early Silurian, when the East Avalonia plate docked with Baltica, and peaked in the late Silurian when Baltica collided with Laurentia. The most significant faulting in the Baltic Basin occurred during the final stage of this collision in the Early Devonian, Lochkovian (Poprawa et al., 1999). The Variscan succession (Lower Devonian, Pragian-lower Carboniferous) is of lesser extent, attains a thickness of $0.8 \mathrm{~km}$, and is present mainly in Lithuania and Latvia (Matyja, 2006). It is mainly composed of Devonian terrigenous deposits and carbonate rocks. This succession belongs to the Devonian-Early Carboniferous intracratonic basin, its remnants unconformably overlying the Upper Ediacaran-Lower Devonian strata (Šliaupa and Hoth, 2011). The Alpine succession includes upper Permian carbonates and evaporites (present in Western Lithuania) as well as Mesozoic and Cenozoic sedimentary rocks (Paškevičius, 1997; Molenaar et al., 2019). This succession is a part of the Permian -Mesozoic Central European Basin System, Western Lithuania being at its edge (Poprawa, 2019). Within our study area, the sedimentary cover is composed of Caledonian, Variscan and Alpine successions; it is $\sim 2.0-2.3 \mathrm{~km}$ thick and thickens west- 
wards (Poprawa et al., 1999; Stirpeika, 1999; Poprawa, 2019). Our study area belongs to the Gdańsk-Kura depression (the structural units of the Baltic Basin are after Brangulis et al., 1993), one of the deepest parts of the basin, where the total thickness of the sedimentary cover reaches $4 \mathrm{~km}$ (Fig. 1A). This depression contains hydrocarbon accumulations, for which the main hydrocarbon reservoir is the middle Cambrian sandstone, sealed by Ordovician and Silurian shales and marls (Brangulis et al., 1993).

In Western Lithuania, the Cambrian terrigenous deposits, composed of sandstones, siltstones and shales, overlie the crystalline basement. They consist of the shale-dominated Gege, Virbalis and Kybartai formations (the Aisčiai Group) of the lower Cambrian and the sandstone-dominated Pajūris, Ablinga, Giruliai formations (the Deimena Group) of the middle Cambrian, separated by the Hawke Bay unconformity (Nielsen and Schovsbo, 2011, 2015; Nielsen and Ahlberg, 2019). The Ordovician rocks unconformably overlie the Cambrian and consist of a variety of carbonates, marls and shales and are divided into numerous thin formations (Jaanusson, 1973; Paškevičius, 1997). In Western Lithuania, the thickness of the Cambrian is 100-150 m (>250 m in the Lithuanian offshore) and smoothly thickens westwards, while the Ordovician is 60-200 m thick and smoothly thickens northwards. Within our study area, the typical thickness of the Cambrian is 125-150 m, while the Ordovician is $80-100 \mathrm{~m}$ thick.

Among the interesting features of the Baltic Basin are Paleozoic carbonate build-ups and reefs. Late Ordovician (Katian) carbonate mounds formed around the island of Gotland and offshore Latvia (Kanev et al., 2001; Sivhed et al., 2004; Tuuling and Flodén, 2000, 2007). Silurian reefal structures are known in Gotland, between Gotland and Saarema (Flodén et al., 2001; Tuuling and Flodén, 2011, 2013), and in Latvia and central Lithuania (Kanev et al., 2001; Kaminskas et al., 2015).

Neither Ordovician carbonate mounds nor Silurian reefs developed in our study area, Western Lithuania, where a deeper marine environment prevailed (Paškevičius, 1997; Levendal et al., 2019).

Since the peneplanated Precambrian surface was almost flat, and the Cambrian deposits are rather thin (as compared to the thickness of, for example, Silurian deposits) and widespread within the Baltic Basin, one can expect the thickness of the Cambrian to change smoothly. However, in Western Lithuania there is evidence of considerable change in Cambrian thickness, or even its absence, over short distances. This reduction of Cambrian thickness is local, being reported from a few tens of exploration boreholes that reach the Precambrian crystalline basement (Stirpeika, 1999). The top of the crystalline basement in these boreholes is weathered. It includes drape structures: configurations of strata that in vertical section have the appearance of gentle anticlines but form due to differential compaction of layers around pre-existing elevations. These elevations cause local reduction of thickness of the Cambrian strata (Stirpeika; 1999, Šliaupa and Hoth, 2011).

\section{MATERIAL AND METHODS}

The study area is located in Western Lithuania and is limited by the regionally important Telšiai Fault to the north, the Baltic Sea and the Curonian Lagoon to the west, the edge of the Zechstein evaporite basin to the south and an absence of seismic data to the east (Fig. 2). Due to its hydrocarbon potential, this is the best explored part of Western Lithuania in terms of the number of acquired seismic surveys. In addition, other parts of Western Lithuania outside our study area have also been surveyed by $2 \mathrm{D}$ and $3 \mathrm{D}$ seismic surveys, and the offshore areas of Poland, the Kaliningrad District, Lithuania and Latvia have been surveyed with densely spaced $(2 \mathrm{~km}) 2 \mathrm{D}$ seismic lines.

Both 2D and 3D onshore reflection seismic data from Western Lithuania were used in this study. The new seismic data, mostly acquired after the year 2000, were preferred to older data because the old data tend to have issues such as incorrect near-surface static corrections, low fold, and low signal to noise ratio. Eleven 3D seismic surveys, which in total cover an area of $550 \mathrm{~km}^{2}$, as well as nearly $3002 \mathrm{D}$ lines, which have a total length of just under $2000 \mathrm{~km}$, constitute our data set (Fig. 2). Approximately $25 \%$ of the study area is covered by $3 \mathrm{D}$ seismic data, and the density of $2 \mathrm{D}$ seismic lines is $1-4 \mathrm{~km}$ of the profile length per square kilometre.

Seven of the 3D seismic surveys overlap and have similar survey acquisition parameters; therefore, they were merged into, and processed as, one data set using a standard post-stack time processing sequence. Only additional post-stack random noise attenuation was applied to other 3D data sets and all of the 2D data sets. For the merged survey (marked "R" in Fig. 2), there exist near-surface velocity surveys, so a near-surface velocity model was made, and near-surface static corrections were calculated and applied. Consequently, this data set has a reliable seismic reference datum and was used as the reference data set. The other ten 3D seismic data sets and all of the nearly $3002 \mathrm{D}$ seismic lines were positioned on the same seismic reference datum by applying appropriate time shifts. These shifts were obtained by making one interpreted horizon in intersecting (overlapping) surveys be at the same two-way-time at the points of intersection (points of overlap). In the case of overlapping 3D and 2D surveys, preference was given to the $3 \mathrm{D}$ surveys. In the case of overlapping 2D surveys, preference was given to the most recent survey. Only a few "old" 2D lines were used, mostly to relate distant surveys and to fill not-recently-surveyed areas.

The interpretation of seismic reflectors (horizons) in the seismic data is the basis of our work. The procedure of structural interpretation (Brown, 2011) was followed. Two regionally recognizable reflecting surfaces were interpreted: the top of the Ordovician and the top of the Precambrian crystalline basement. The top of the Ordovician is the most prominent regional reflector, where carbonate-dominated Ordovician is overlain by calcareous shale-dominated Silurian. The top of the crystalline basement is another regional reflector, where crystalline rocks are mostly overlain by terrigenous Cambrian deposits. Both horizons represent an increase in acoustic impedance. Horizons in between the top of the Ordovician and the top of the crystalline basement (for example, the top of the Cambrian) could not be interpreted within our study area because the different lithological units - formations - are often only a few metres thick and well below the vertical resolution of the seismic data.

The spatial precision of the interpreted horizon is determined by the type of seismic data (2D or 3D) and by bin size, which is usually $12.5 \mathrm{~m}$ for $2 \mathrm{D}$ seismic lines, and $25 \times 25 \mathrm{~m}$ for $3 \mathrm{D}$ seismic volumes. The time horizons were created on a grid of $50 \times 50 \mathrm{~m}$ within the entire study area. The interpreted time horizons were converted to depth horizons (horizons) using the model of horizon velocity (that is, the model of average-velocity-to-horizon). Such a velocity model can be obtained using at least one well with a velocity survey and many wells with a certain well top. This apparently simple time-to-depth conversion suits the geological conditions of our study area, where the velocity field is laterally smooth. Here, it does not have substantial anomalies which can be caused by, for example, Silurian reefs or Ordovician carbonate mounds. 


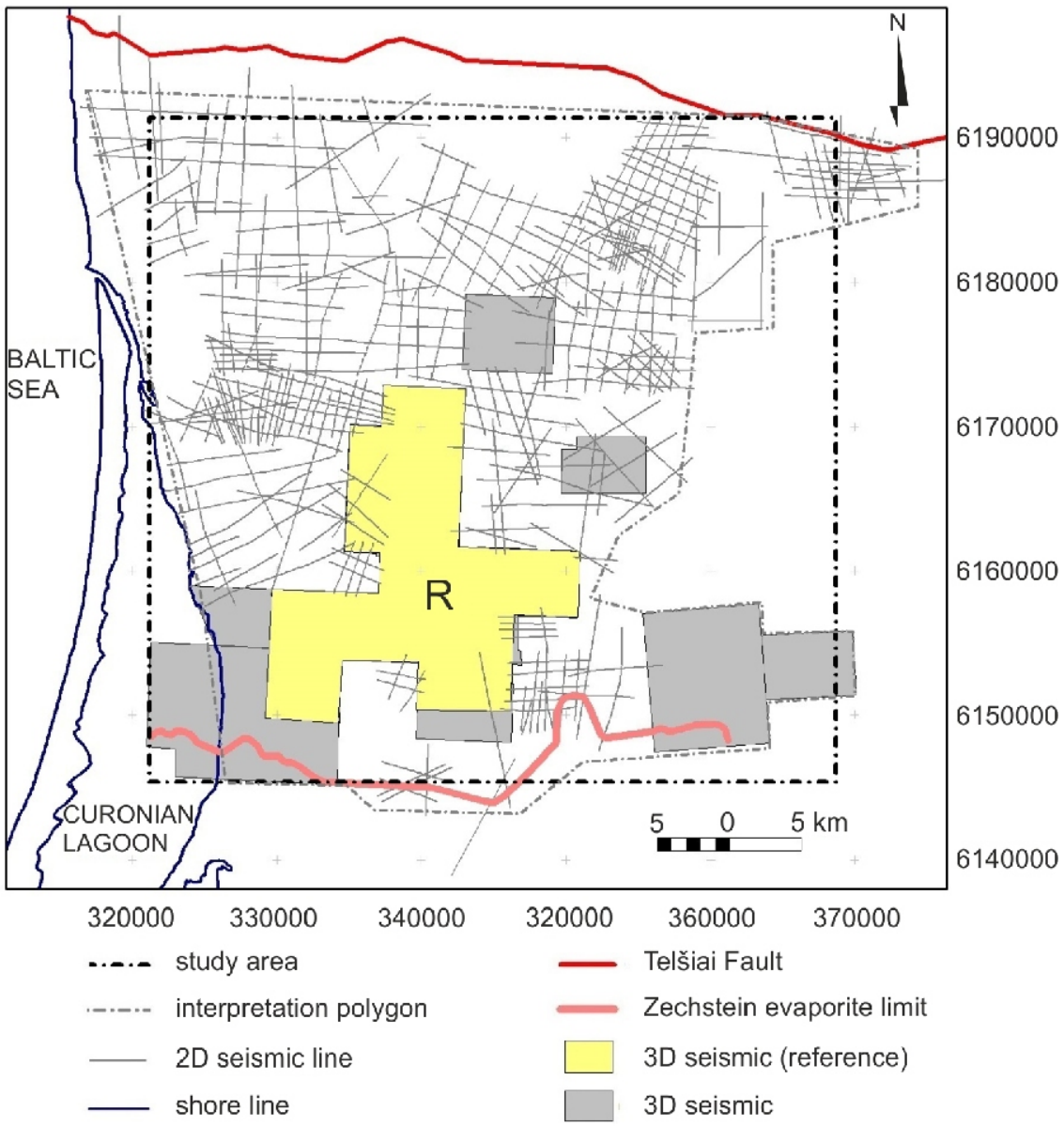

Fig. 2. Study area and position of seismic surveys

Study area is limited by the Telšiai Fault to the north, the Baltic Sea and the Curonian lagoon to the west, the edge of the Zechstein evaporite basin to the south and an absence of seismic data to the east. Seismic surveys used in this work: 3D seismic surveys are shown by grey and yellow ( $R$ - reference) shaded areas, 2D seismic lines are shown by thin grey lines

The seismic interpretation was made using LMKR Geographix seismic interpretation software. Figures were made using either the seismic interpretation software or Matplotlib (Hunter, 2007). The coordinate system is LKS94 or UTM 34N for figures representing regional context.

\section{RESULTS}

\section{SECTIONS AND HORIZONS}

The main seismic reflectors (horizons) in our study area, being also of regional importance, are: $\mathrm{Pr}$ - the top of the Precambrian crystalline basement, $\mathrm{Or}$ - the top of the Ordovician, S2db - the top of the Dubysa Formation in the upper Silurian, S2 - the top of the upper Silurian, D1 - the top of the Lochkovian in the Lower Devonian, and P - the top of the Permian (Fig. 3). Strata between Pr and D1 belong to the Caledonian succession, strata between $\mathrm{D} 1$ and $\mathrm{P}$ belong to the Variscan succession, and strata between $\mathrm{P}$ and the ground surface belong to the Alpine succession. Strictly speaking, the whole upper Permian belongs to the Alpine succession, but in Western Lithuania the upper Permian is thin and its top and bottom cannot be distinguished as separate reflectors in seismic sections. Only the top of the Precambrian crystalline basement $(\mathrm{Pr})$ and the top of the Ordovician (Or) are relevant to this study. The geological structure of our study area is rather simple: the horizons are nearly flat, smooth, and the thickness of strata between horizons also varies smoothly. The section is complicated by Caledonian faults of relatively small throw (maximum $\sim 150 \mathrm{~m}$ ).

The horizons of the top of Ordovician (Fig. 4) and the top of Precambrian crystalline basement (Fig. 5) were interpreted only where the new seismic data exist, hence the irregular interpretation polygon and spatial extent of the horizons. The top of Ordovician is at $1860-2040 \mathrm{~m}$, and the top of Precambrian crystalline basement is at 1960-2310 m, below mean sea level. Though both the Or and Pr horizons are generally smooth, they are complicated by general westwards deepening and Caledonian faults. The top of the Ordovician often mimics the crystalline basement, except in the southeastern part of the study area.

\section{THICKNESS OF THE SUCCESSION LIMITED BY THE OR AND PR HORIZONS}

The thickness of strata between the top of the Ordovician (Or) and top of the crystalline basement (Pr) (Fig. 6) was obtained from the difference in burial depth of both horizons. The 


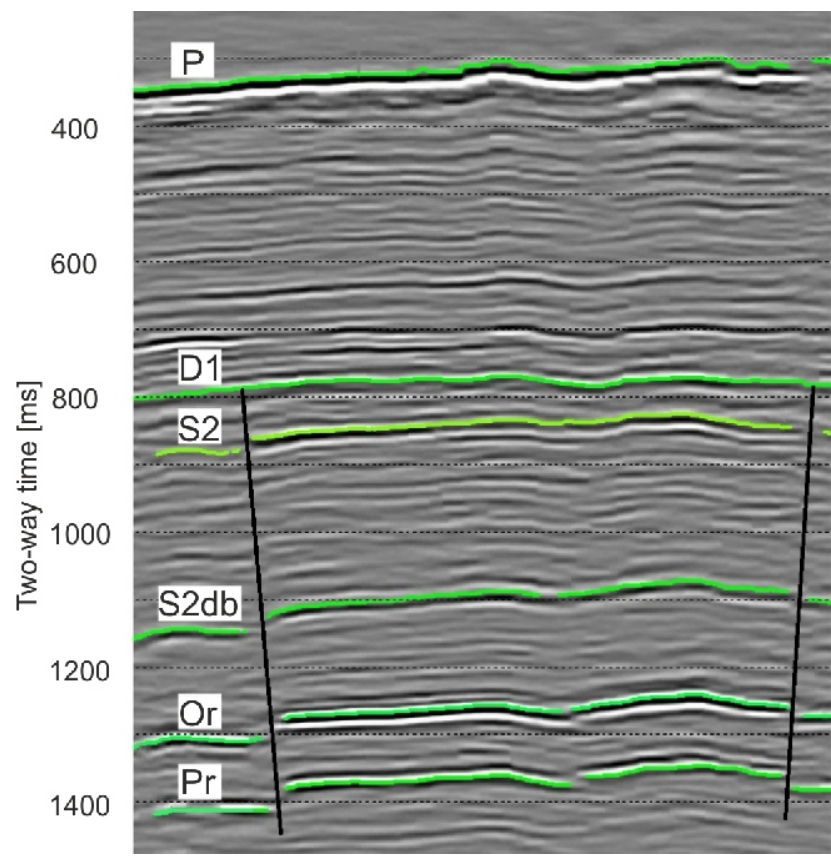

Fig. 3. Typical vertical seismic section in Western Lithuania with interpreted horizons

P - the top of the Permian, D1 - the top of the Lochkovian in the Lower Devonian, S2 - the top of the Silurian, S2db - the top of the Dubysa Formation within the upper Silurian, Or - the top of the Ordovician, $\mathrm{Pr}$ - the top of the crystalline basement. The horizontal distance displayed in this section is $8 \mathrm{~km}$

study area can be divided into two domains (Fig. 6): (1) an area of greater (200-250 m), rather constant and smoothly varying thickness in the northwest and (2) an area of smaller (50-150 m) and irregular thickness in the south-east.

The thickness patterns exclude: (1) the general westwards tilt of the crystalline basement and overlying strata, (2) the faults that occurred in the late Silurian-Early Devonian in relation to the Caledonian orogeny and that displace sedimentary rocks. In this way the sedimentary rocks above the Ordovician have been stripped off, and the top of Ordovician is reconstructed to the flat surface which existed at the time of deposition at the end of Ordovician, while the top of Precambrian crystalline basement is reconstructed to nearly its original topography. In general, this is a valid approximation because in the Baltic Basin there was no rapid subsidence or uplift in our study area in the early Paleozoic. The lesser thickness in the southeastern part of the study area indicates both the lack of sedimentary rocks and the positive topography of the Precambrian crystalline basement.

\section{PRECAMBRIAN PALAEOTOPOGRAPHY}

If the flat surface of sub-Cambrian peneplain had been present across the entire study area, then only a relatively small and smooth variation in Or-Pr thickness may be expected over a large horizontal distance. However, in the southeastern part of the study area we observe a sharp change in Or-Pr thickness which in turn represents a sharp palaeotopography transition from peneplain-like flat to more hilly terrain. The area with rougher palaeotopography in the southeastern part of the study area is at least $30 \mathrm{~km}$ wide while its highest points are 100-150 $\mathrm{m}$ above the flat peneplain's surface. We cannot determine its full extent because we do not have seismic data east of our study area.
Based on the map in Figure 6, the extent of palaeotopography features was evaluated (Fig. 7). The following groups of features were distinguished: (1) Ablinga - a cluster in the northeastern part of the study area, (2) Šiūpariai, (3) Veiviržènai, (4) Pociai-Lašai, (5) Šilalè, (6) small unnamed features between Šiūpariai, Veiviržènai, Pociai-Lašai and Šilalè. The Ablinga cluster lies outside the main high palaeotopography area and is comprised of six individual features (A and B - Ablinga, C and D - Žadeikiai, E - Ližiai, F Mostaičiai). Šiūpariai $A$ is a large feature of irregular shape with a diameter of $6-7 \mathrm{~km}$. Veiviržènai $A$ is the largest and roundest feature in our study area with a diameter of at least $7-8 \mathrm{~km}$. It is also the highest, and the thickness of sedimentary rocks above this feature is the smallest, to that extent that the Cambrian strata are completely missing (Fig. 6). Pociai-Lašai is a cluster of at least four individual features with Pociai A being the largest ( $\sim \mathrm{km}$ in diameter, the others being 1-3 km). Šilalè is of irregular and elongated shape, $\sim 12 \mathrm{~km}$ long and $\sim 4 \mathrm{~km}$ wide; it is oriented $\mathrm{E}-\mathrm{W}$ and has three parts (A, B and $\mathrm{C})$. There are many small features in between Šiūpariai, Veiviržènai, Pociai-Lašai and Šilalè, which are not named and not assigned to any feature group.

The palaeotopography of sub-Cambrian peneplain inferred from the present-day Or-Pr thickness is approximate because (1) there exist unconformities in the lower/middle Cambrian (the Hawke Bay unconformity), and in the upper Cambrian and the Upper Ordovician, (2) the sedimentary rocks experienced a certain amount of compaction from the sedimentary overburden while the crystalline rocks did not.

\section{SEISMIC SECTIONS OF DRAPE STRUCTURES}

The additional complexity of the top of Precambrian crystalline basement $(\mathrm{Pr})$ and its sedimentary cover in the southeastern part of our study area can be demonstrated by seismic sections (Fig. 8). This complexity is the result of "hill"-like features of the basement. The top of the Ordovician drapes the Precambrian features. The draping is caused by the differential compaction of the Ordovician and Cambrian sedimentary rocks, resulting in reductions of their thickness. This led to the formation of drape/compaction structures above the positive palaeotopography of the crystalline basement.

\section{DISCUSSION}

\section{WESTERN LITHUANIA CONTEXT}

Only some of the palaeotopography features within our study area were known previously: Šiūpariai $A$, Veiviržènai $A$, Pociai A, Šilalè B and Ablinga B (Stirpeika, 1999). The rest - the Ablinga cluster, Pociai-Lašai cluster, Šilalè's true shape, and many small features between Šiūpariai, Veiviržènai, Pociai-Lašai and Šilalè - are newly mapped (Fig. 7). Moreover, the true extent of these features within our study area, both newly mapped and known previously, is now mapped to very high precision using $2 \mathrm{D}$ and $3 \mathrm{D}$ seismic data.

The palaeotopography features of the Precambrian crystalline basement are not unique to our study area. In Western Lithuania, outside our study area, a few palaeotopography features are present: Plungè in the north, Baubliai in the east, Lauksargiai in the south (Fig. 9). All of these are confirmed by boreholes, that is, smaller Or-Pr succession thickness at the expense of the lower part of the Cambrian or even an absent Cambrian, hence high Precambrian palaeotopography. 


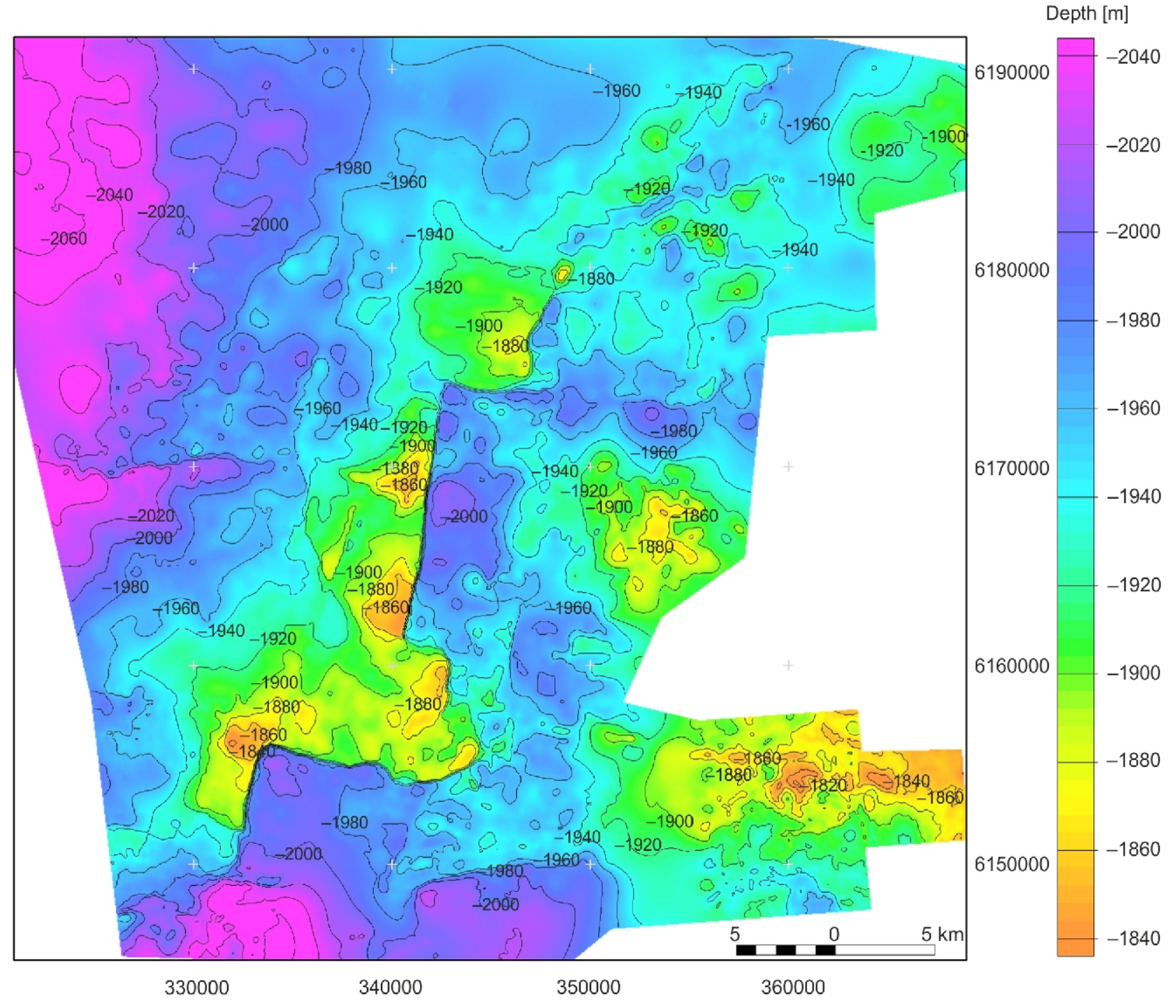

Fig. 4. Horizon of the top of the Ordovician (Or)

Depth is in metres below mean sea level. Depth is indicated by colour scale, contours of equal depth and depth values on contours. Contours of equal thickness are drawn every $20 \mathrm{~m}$

\section{BALTIC SEA REGION CONTEXT}

The palaeotopography features of the Precambrian crystalline basement, which itself is the surface of the sub-Cambrian peneplain, are not unique to Western Lithuania, being also reported outside Western Lithuania (Fig. 10). Firstly, near the coast of Sweden there is the Jungfrun inselberg (the island of BII Jungfrun; Fig. 10A; Lidmar-Bergström, 1995; Lidmar-Bergström et al., 2017). The Lower Cambrian is absent in one well (B-10) in the Swedish offshore area (Fig. 10B) (Sopher et al., 2016). In Northern Poland there is one palaeotopography feature of irregular shape $<10 \mathrm{~km}$ in diameter, and 6 small ( $<5 \mathrm{~km}$ diameter) features (Fig. 10C; Stirpeika, 1999; Modliński et al., 1999). One palaeotopography feature which has a weathering crust and is directly overlain by the middle Cambrian (the lower Cambrian is absent) is reported from the Kaliningrad District (Fig. 10C; Meshcherskii et al., 2003). Knowledge concerning the pre-Cambrian palaeotopography features from the onshore of Kaliningrad District is incomplete due to unavailable data. The offshore area of Lithuania and the Kaliningrad District is nearly devoid of such features - only 5 small, isolated palaeotopography features have been identified, and none of them was drilled (Fig. 10D; VO Tekhnoeksport, 1985). A sparse group of 15 small, irregularly distributed palaeotopography features is reported in an area spanning $\sim 100 \mathrm{x} \sim 50 \mathrm{~km}$, offshore Latvia between the island of Gotland and the coast of Latvia (Fig. 10E). One of these features, Piltene (Latvia onshore), is confirmed by a well (Brangulis and Kanevs, 2002). In Northern Estonia near the Gulf of Finland, a closely spaced group of 6 small palaeotopography features is reported (Fig. 10F). They are 1-3 km in diameter, <100 $\mathrm{m}$ high and are directly overlain by Cambrian and/or Ediacaran strata. Half are confirmed by boreholes (Estonian Land Board, Geological Survey of Estonia, 2020, Ani and Meidla, 2020).

These palaeotopography features are small, usually $1-3 \mathrm{~km}$ in diameter and reach $<100 \mathrm{~m}$ above the peneplain. The well data from Western Lithuania and Kaliningrad District indicate that such features can have a weathering crust. Therefore, these small features can be interpreted as inselbergs that rise above the sub-Cambrian peneplain. Inselbergs occur either as isolated features, as very sparse groups of features or as feature clusters (Figs. 7 and 10). The Jungfrun inselberg is 
Depth $[\mathrm{m}]$

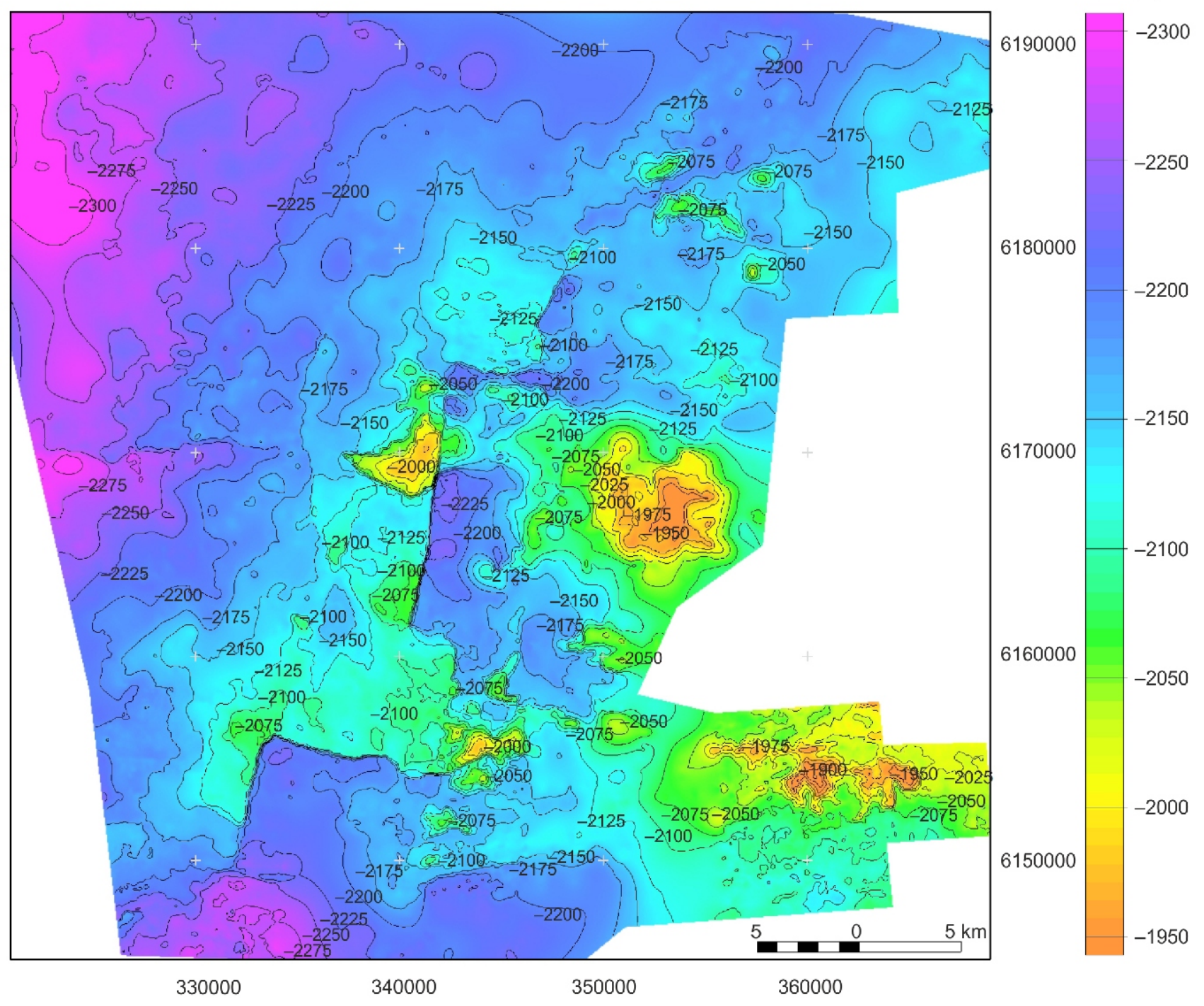

Fig. 5. Horizon of the top Precambrian crystalline basement (Pr)

Depth is in metres below mean sea level. Depth is indicated by colour scale, contours of equal depth and depth values on contours Contours of equal thickness are drawn every $25 \mathrm{~m}$

an example of an isolated feature (Fig. 10A). A sparse group can be characterized by the large distance between features compared to the feature diameter. Inselbergs in the Lithuanian and Latvian offshore are examples of sparse groups of features (Fig. 10D, E). A cluster can be characterized by the feature diameter being of the same order as the distance between features. Zaręby, North Poland (Fig. 10C), a cluster in North Estonia (Fig. 10F), also the Ablinga Group (Fig. 7) are examples of such clusters.

\section{ARRAY OF INSELBERGS}

The palaeotopography style observed in the southeastern part of our study area (many "hills" of various size) is very different from that in the western part of our study area (peneplain-like flat), and the change from one pattern to another is sharp.

Firstly, not only the western part of our study area does not have palaeotopography features - only 5 sparsely distributed features are identified in the Lithuanian and the Kaliningrad Dis- trict offshore area. This number is reliable because: (1) the entire southeastern part of Baltic Sea has been surveyed with a dense network of 2D seismic lines (VO Tekhnoeksport, 1985), (2) both the top of Precambrian crystalline basement and the top of Ordovician are clearly identifiable offshore Lithuania (Fig. 6), (3) this same featureless style of the top pre-Cambrian crystalline basement is typical of the Swedish offshore area (Sopher and Juhlin, 2013, Sopher et al., 2016); hence, it is typical of the Baltic Basin between Sweden and the Baltic States.

Secondly, the extent of the "hilly" southeastern part is at least $30 \mathrm{~km}$, but its full extent to the east cannot be determined from our study, and just east of our study area there is another large palaeotopography feature: Baubliai (Fig. 9). There may be more palaeotopography features between our study area and Baubliai; the amount of seismic data ever recorded onshore decreases towards the east and north.

Due to the different topographic style of the southeastern part of our study area, its considerable size and expected extent to the east, and the size, number, and density of individual palaeotopography features, we propose that the southeastern 
Thickness [m]

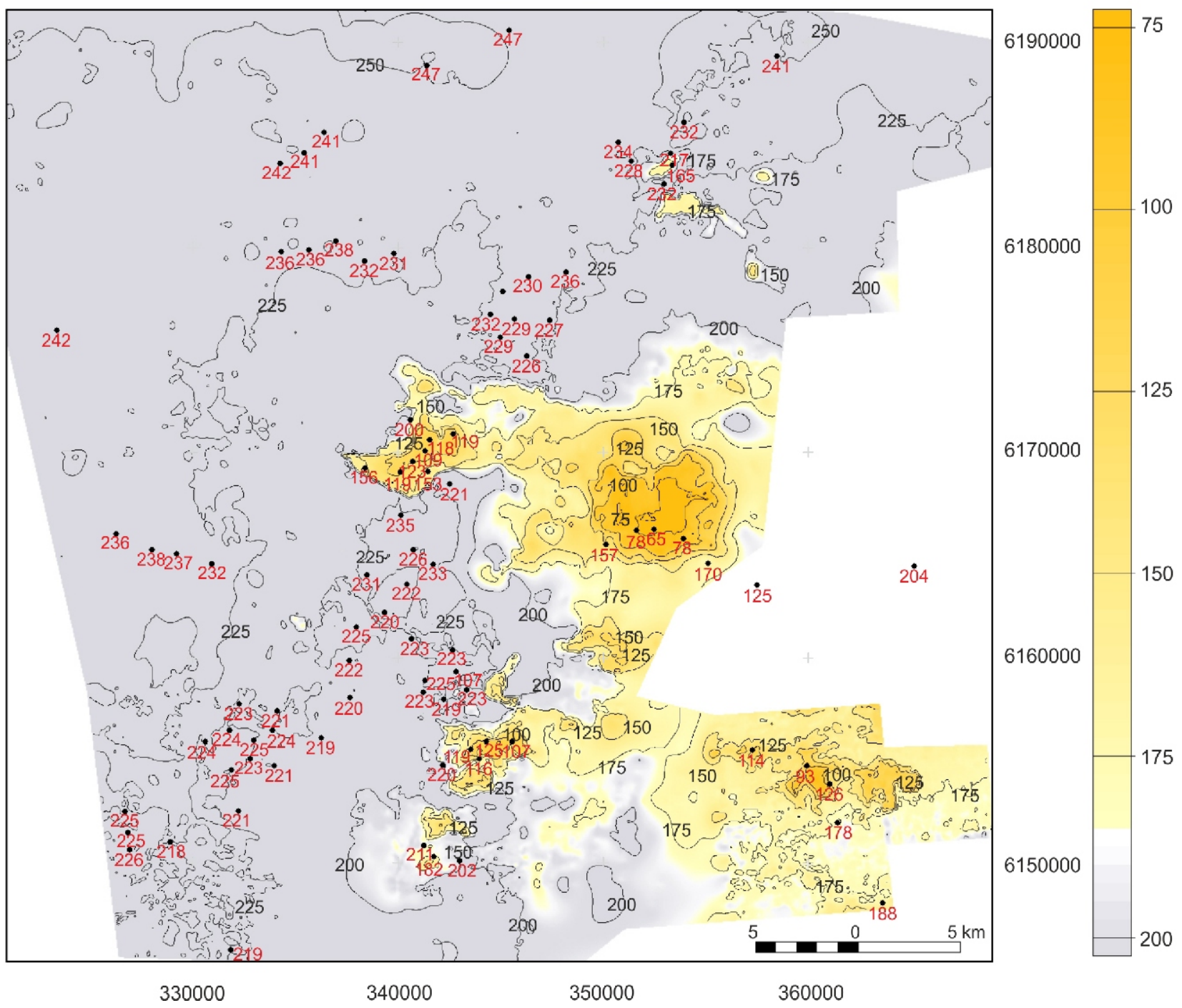

Fig. 6. Thickness of Cambrian and Ordovician strata together, obtained as the difference between the horizons of the top of the Ordovician (Or) and the top of the pre-Cambrian crystalline basement (Pr)

Depth is indicated by colour scale (grey - thick, yellow - thin), contours of equal depth and depth values on contours. Contours of equal thickness are drawn every $25 \mathrm{~m}$. Black dots mark wells with both top of Or and top of Pr constrained; numbers below borehole symbols show actual thickness in those boreholes in metres

part of our study area is part of a large array of inselbergs. On a local scale (our study area), this does not comply with the definition of a peneplain (Phillips, 2002), but on a broader scale it is still a feature of a peneplain, because its diameter is of the order of tens of kilometres while the extent of the peneplain is sub-continental (a few hundreds or thousands of kilometres across). This array of inselbergs is the largest and densest group, cluster, or array of inselbergs discovered so far within the Baltic Sea region.

\section{ORIGIN OF THE INSELBERG ARRAY}

The type of rock that constitutes the pre-Cambrian palaeotopography features can be either the original Paleoproterozoic crystalline basement rocks or the Jotnian strata. For example, in our study area, the pre-Cambrian basement features are mainly composed of Paleoproterozoic rocks while strata attributed to Jotnian occur around the pre-Cam- brian features (Stirpeika, 1999). However, Jotnian quartzite has been found (Fig. 10B) and is interpreted as a monadnock (Sopher et al., 2016). In both cases, these palaeotopography features can be explained as remnants of erosion. The relative resistance to erosion can be caused by different types of crystalline basement rocks. However, in our study area, the different rock types of the crystalline basement do not relate to the occurrence of inselbergs (the geological map of the crystalline basement of Lithuania in Motuza et al., 2008). Linear or elongated landforms of various size can be formed by glacial erosion (Dowdeswell et al., 2016), but the inselberg array in our study area does not show any consistent linear pattern (Fig. 7). Also, the largest inselbergs in this array have irregular edges and usually have their maximum height in their central part (Figs. 6 and 7), as if erosion equally affected all their sides. The southeastern part of our study area may have had a generally higher topography, which possibly extended to the east. This could explain why the area was subjected to erosion last - it did 


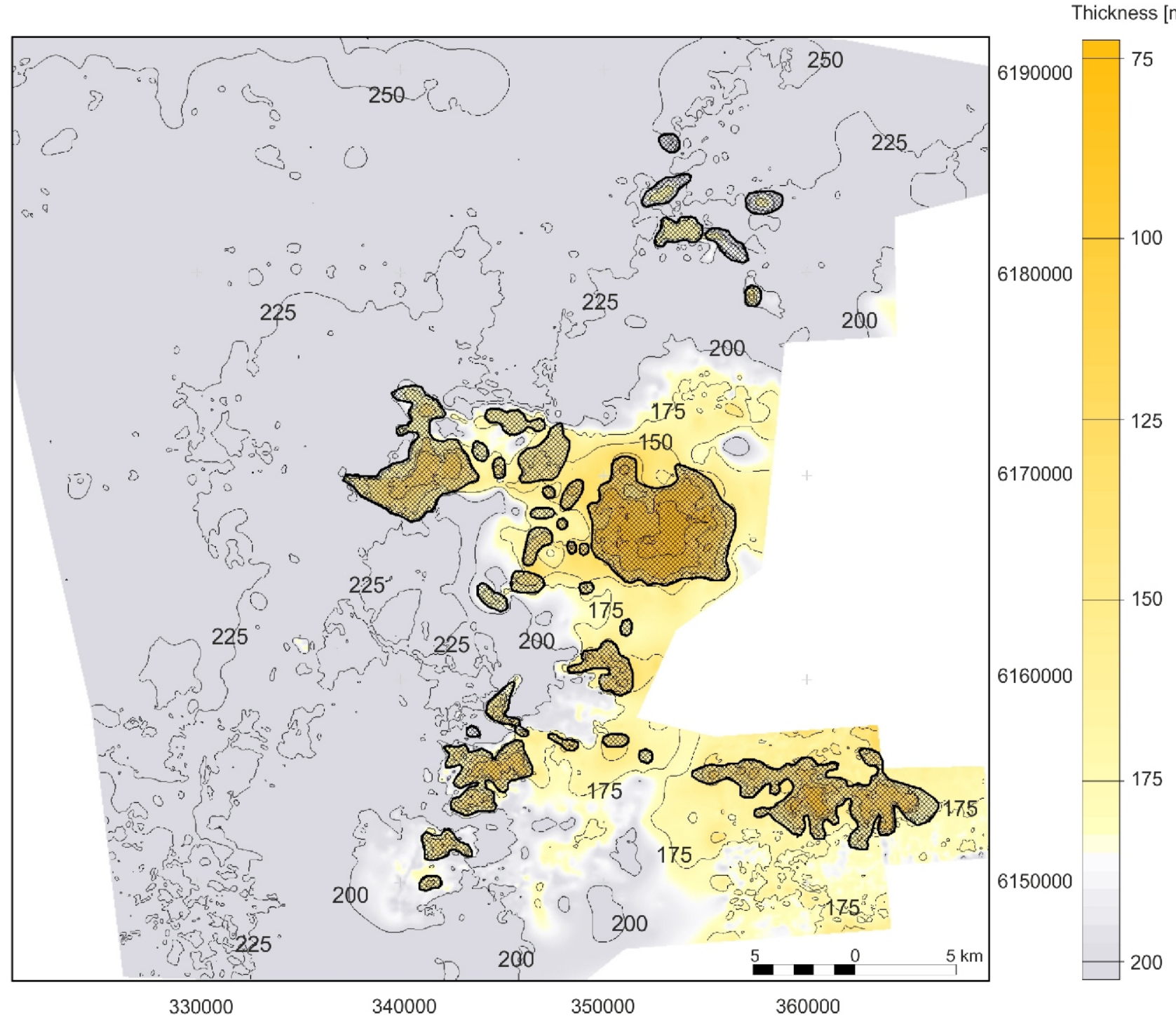

Fig. 7. Full areal extent of the Precambrian crystalline basement topographic features (shaded areas) overlain over the thickness of the Cambrian and Ordovician strata (Fig. 6)

not reach the final stage of peneplanation and included inselbergs at the time of Cambrian transgression.

A different proposition was made by Sopher et al. (2016) for an apparently similar situation. Northeast of the island of Gotland (Fig. 10G) the Precambrian basement is overlain by Cambrian and is reported to have a "rugose topography". This is interpreted as due to fluvial erosion, which took place near the edge of the pre-Cambrian basin. However, such an interpretation is uncertain because the sub-Cambrian peneplain surrounds that location (Fig. 1A). Similarly, our study area in Western Lithuania is limited and it does not reveal the full extent of the inselberg array (Figs. 7 and 9). From this, it cannot be concluded definitively that the edge of the basin has been observed; rather, this large array of inselbergs is a remnant of erosion.

\section{CONCLUSIONS}

Using modern 2D and 3D onshore seismic data from Western Lithuania, two regionally recognizable reflecting surfaces have been interpreted: the top of Ordovician and the top of pre-Cambrian crystalline basement.

From west to east, the palaeotopography of the Precambrian crystalline basement changes from peneplain-like flat to relatively high and rough. The flat western side of our study area is interpreted as a continuation of the sub-Cambrian peneplain, which outcrops in Scandinavia while to the southeast it is buried beneath strata of the Baltic Basin. The southeastern part of our study area has many closely spaced hill-like features of various size, is of considerable extent (at least $30 \mathrm{~km}$ ) and does is not consistent with a peneplain on a local scale. It is interpreted as part of a large array of inselbergs. This array of inselbergs is exceptional because it is the largest and densest of all known groups or clusters of inselbergs known in the Baltic Basin. In the Baltic Sea region there also exist pre-Cambrian/pre-Ediacaran palaeotopographic features buried beneath the strata of the Baltic Basin. They occur either as isolated features, as very sparse groups of features, or as feature clusters and can be interpreted as inselbergs. The diameter of separate palaeotopographic features varies from 1-3 km to $10 \mathrm{~km}$, and their height from $<100$ to $\sim 150 \mathrm{~m}$. 

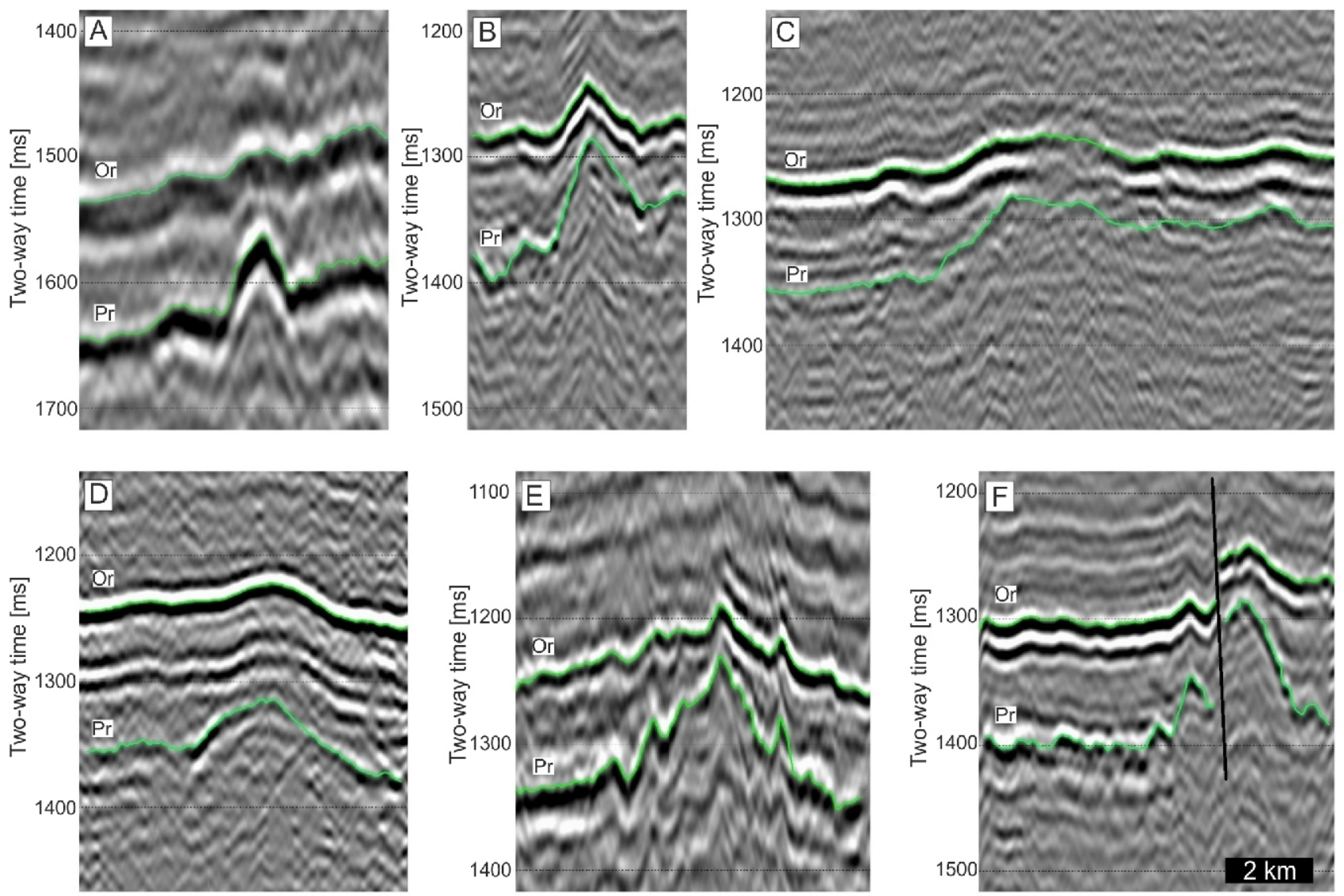

Fig. 8. 2D seismic sections with examples of pre-Cambrian crystalline basement topographic features

$\mathrm{Or}$ - top of Ordovician, $\mathrm{Pr}$ - top of pre-Cambrian. The length of the black ribbon at the bottom right corner of the last section corresponds to a horizontal distance of $2 \mathrm{~km}$; the same scale applies to all of these sections. Feature name, position and size (see also Fig. 7): A - unnamed isolated feature in the Lithuanian offshore area (outside our study area), diameter $<2 \mathrm{~km}$; B - Pociai A, N-S section, diameter $\sim 3 \mathrm{~km}$; C Veiviržènai A, largest feature in the study area, diameter up to $10 \mathrm{~km} ; \mathbf{D}$ - Ablinga B, diameter $\sim 4 \mathrm{~km}$; E - Šilalè B, diameter $\sim 5 \mathrm{~km}$; F - Pociai $\mathrm{A}, \mathrm{E}-\mathrm{W}$ section, diameter $>3 \mathrm{~km}$. Diameter is approximate and is evaluated from the bases of the topographic features

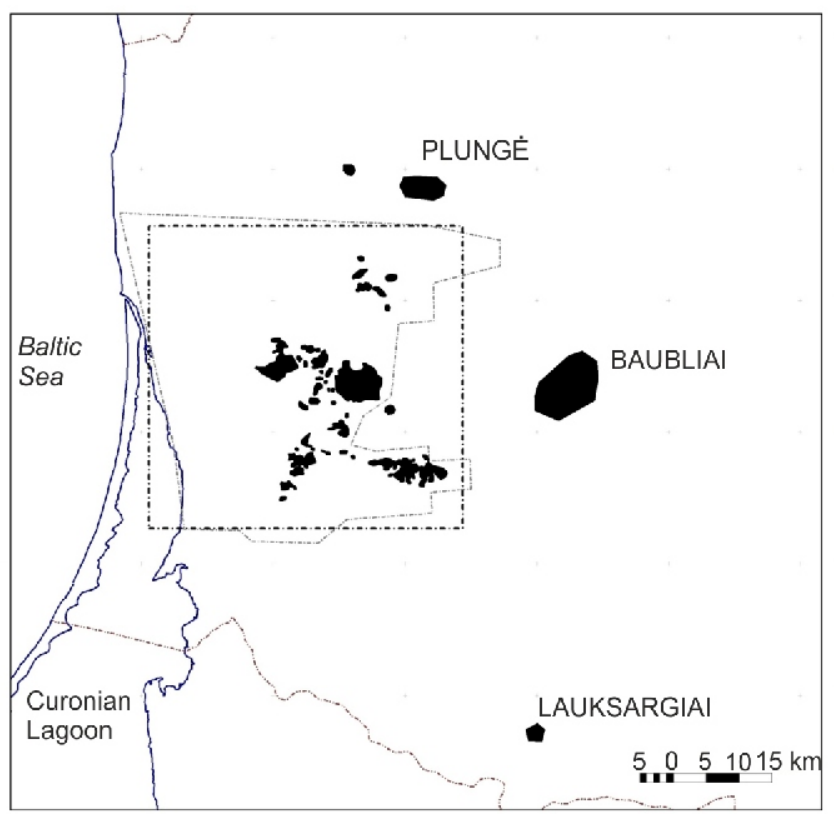

From seismic interpretation, a continuation of the sub-Cambrian peneplain was identified in Western Lithuania. A large array of inselbergs was mapped to the detail that 3D seismic can permit. Though some of the largest palaeotopographic features of the crystalline basement were known before, the detailed mapping revealed that in Western Lithuania there is a large and dense array of inselbergs. This is the largest group of inselbergs ever discovered and described in the Baltic Basin, and its extent can be expected to be even larger.

Acknowledgements. We thank S. Kanevs for valuable discussion.

Fig. 9. Precambrian crystalline basement topographic features (black areas) in Western Lithuania, within our study (detailed) area and outside it (sketch)

Black rectangle defines our study area, grey polygon defines the interpretation polygon, and the main palaeotopographic features are named 


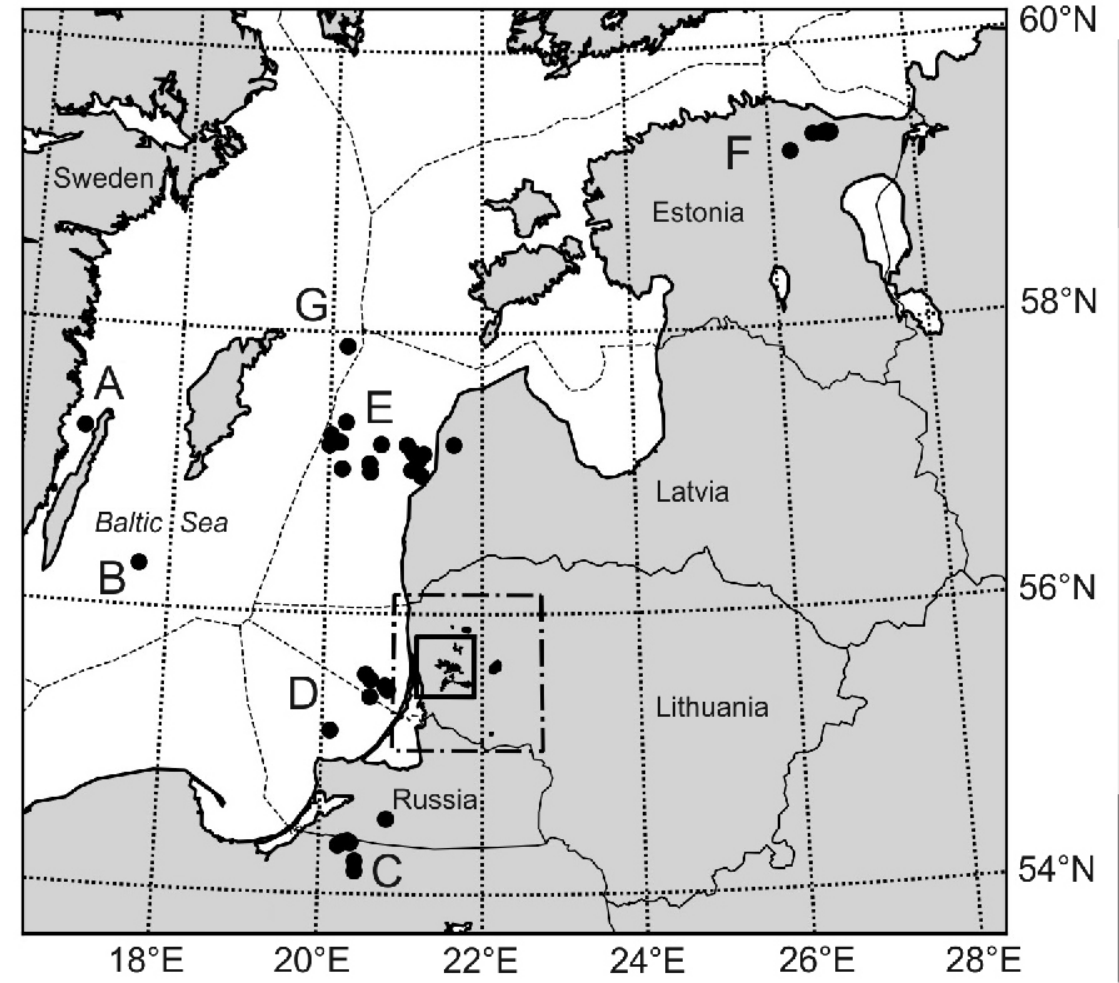

Fig. 10. Pre-Cambrian crystalline basement palaeotopographic features within the Baltic Sea region

Black solid rectangle defines our study area (Fig. 7), black dashed-dotted rectangle defines Western Lithuania as shown in Figure 9. Black dots show the topographic features at their location, but not their true size (except our study area and the rest of Lithuania onshore which are shown to their true scale). A - Blå Jungfrun, Sweden, B - missing Lower Cambrian in one well, east of Sweden, C - Zareby, North Poland, D - unnamed, Lithuania and Kaliningrad District offshore, E - Piltene, Latvia onshore, and the rest unnamed, Latvia offshore, F North Estonia, G - rugose topography, northeast of Gotland. See text for more explanation

\section{REFERENCES}

Ani, T., Meidla, T., 2020. Rock head elevation model of northern Estonia. Estonian Journal of Earth Sciences, 69: 109-120.

Bogdanova, S., Gorbatschev, R., Skridlaite, G., Soesoo, A., Taran, L., Kurlovich, D., 2015. Trans-Baltic Palaeoproterozoic correlations towards the reconstruction of supercontinent Columbia/Nuna. Precambrian Research, 259: 5-33.

Bonow, J.M., Lidmar-Bergström, K., Näslund, J., 2003. Palaeosurfaces and major valleys in the area of the Kjølen Mountains, southern Norway - consequences of uplift and climatic change. Norsk Geografisk Tidsskrift - Norwegian Journal of Geography, 57: 83-101.

Brangulis, A.J., Kanevs, S., 2002. Tectonics of Latvia (in Latvian). Valsts geologijas dienests, Riga.

Brangulis, A.P., Kanev, S.V., Margulis, L.S., Pomerantseva, R.A., 1993. Geology and hydrocarbon prospects of the Paleozoic in the Baltic region. Geological Society, London, Petroleum Geology Conference series, 4: 651-656.

Brown, A.R., 2011. Interpretation of three-dimensional seismic data, $7^{\text {th }}$ edition. Society of Exploration Geophysicists and American Association of Petroleum Geologists. Dallas, Texas, USA.

Butt, C.R.M., Lintern, M.J., Anand, R.R., 2000. Evolution of regoliths and landscapes in deeply weathered terrain - implications for geochemical exploration. Ore Geology Reviews, 16: 167-183.
Claesson, S., Bogdanova, S.V., Bibikova, E.V., Gorbatschev, R., 2001. Isotopic evidence for Palaeoproterozoic accretion in the basement of the East European Craton. Tectonophysics, 339: $1-18$.

Cocks, L.R.M., Torsvik, T.H., 2005. Baltica from the late Precambrian to mid-Palaeozoic times: the gain and loss of a terrane's identity. Earth-Science Reviews, 72: 39-66.

Dadlez, R., Pokorski, J., Modliński, Z. (ed.), 2007. Geological map of the western and central part of the Baltic depression without Permian and younger formations. Państwowy Instytut Geologiczny, Warszawa.

Dowdeswell, J.A., Canals, M., Jakobsson, M., Todd, B.J., Dowdeswell, E.K., Hogan, K.A., 2016. Introduction: an atlas of submarine glacial landforms. Geological Society of London Memoirs, 46: 3-14.

Dörr, W., Belka, Z., Marheine, D., Schastok, J., Valverde-Vaquero, P., Wiszniewska, J., 2002. U-Pb and Ar-Ar geochronology of anorogenic granite magmatism of the Mazury complex, NE Poland. Precambrian Research, 119: 101-120.

Elvhage, C., Lidmar-Bergström, K., 1987. Some working hypotheses on the geomorphology of Sweden in the light of a new relief map. Geografiska Annaler: Series A, Physical Geography, 69: 343-358.

Flodén, T., Bjerkéus, M., Tuuling, I., Eriksson, M., 2001. A Silurian reefal succession in the Gotland area, Baltic Sea. GFF, 123: 137-152. 
Gabrielsen, R.H., Nystuen, J.P., Jarsve, E.M., Lundmark, A.M., 2015. The sub-Cambrian peneplain in southern Norway: its geological significance and its implications for post-Caledonian faulting, uplift and denudation. Journal of the Geological Society, 172: 777-791.

Estonian Land Board, Geological Survey of Estonia, 2020. Geological Base Map. https://xgis.maaamet.ee/xgis2/page/app/ geoloogia50k

Hunter, J.D., 2007. Matplotlib: a 2D graphics environment. Computing in Science \& Engineering, 9: 90-95.

Jaanusson, V., 1973. Aspects of carbonate sedimentation in the Ordovician of Baltoscandia. Lethaia, 6: 11-34

Japsen, P., Green, P.F., Chalmers, J.A., Bonow, J.M., 2018 Mountains of southernmost Norway: uplifted Miocene peneplains and re-exposed Mesozoic surfaces. Journal of the Geological Society, 175: 721-741.

Jarsve, E.M., Krřgli, S.O., Etzelmüller, B, Gabrielsen, R.H., 2014 Automatic identification of topographic surfaces related to the sub-Cambrian peneplain (SCP) in southern Norway - Surface generation algorithms and implications. Geomorphology, 211: 89-99.

Kaminskas, D., Michelevičius, D., Blažauskas, N., 2015. New evidence of an early Pridoli barrier reef in the southern part of the Baltic Silurian basin based on three-dimensional seismic survey, Lithuania. Estonian Journal of Earth Sciences, 64: 47-55.

Kanev, S., Lauritzen, O., Schmitz, U., 2001. Latvia's first onshore round - its potential and perspectives. Oil Gas European Magazine, 3: 19-23.

Keller, C.B., Husson, J.M., Mitchell, R.N., Bottke, W.F., Gernon, T.M., Boehnke, P., Bell, E.A., Swanson-Hysell, N.L., Petersj, S.E., 2019. Neoproterozoic glacial origin of the Great Unconformity. Proceedings of the National Academy of Sciences, 116 1136-1145.

Konsa, M.K., Puura, V., 1999. Provenance of zircon of the lowermost sedimentary cover, Estonia, East European Craton. Bulletin of the Geological Society of Finland, 71: 253-273.

Levendal, T.C., Lehnert, O., Sopher, D., Erlström, M., Juhlin, C., 2019. Ordovician carbonate mud mounds of the Baltoscandian Basin in time and space - a geophysical approach. Palaeogeography, Palaeoclimatology, Palaeoecology, 535: 109345.

Li, Z.X., Bogdanova, S.V., Collins, A.S., Davidson, A., De Waele, B., Ernst, R.E., Fitzsimons, I.C.W., Fuck, R.A., Gladkochub, D.P., Jacobs, J., Karlstrom, K.E., Lu, S., Natapov, L.M., Pease, V., Pisarevsky, S.A., Thrane, K., Vernikovsky, V., 2008. Assembly, configuration, and break-up history of Rodinia: A synthesis. Precambrian Research, 160: 179-210.

Lidmar-Bergström, K., 1988. Denudation surfaces of a shield area in South Sweden. Geografiska Annaler: Series A, Physical Geography, 70: 337-350.

Lidmar-Bergström, K., 1993. Denudation surfaces and tectonics in the southernmost part of the Baltic Shield. Precambrian Research, 64: 337-345.

Lidmar-Bergström, K., 1995. Relief and saprolites through time on the Baltic Shield. Geomorphology, 12: 45-61.

Lidmar-Bergström, K., Olvmo, M., 2015. Plains, steps, hilly relief and valleys in Northern Sweden - review, interpretations and implications for conclusions on Phanerozoic tectonics. Research paper C838. Geological Survey of Sweden, Uppsala.

Lidmar-Bergström, K., Olsson, S., Olvmo, M., 1997. Palaeosurfaces and associated saprolites in southern Sweden. Geological Society Special Publications, 120: 95-124.

Lidmar-Bergström, K., Bonow, J.M., Japsen, P., 2013. Stratigraphic Landscape Analysis and geomorphological paradigms: Scandinavia as an example of Phanerozoic uplift and subsidence. Global and Planetary Change, 100: 153-171.

Lidmar-Bergström, K., Olvmo, M., Bonow, J.M., 2017. The South Swedish Dome: a key structure for identification of peneplains and conclusions on Phanerozoic tectonics of an ancient shield. GFF, 139: 244-259.

Liivamägi, S., Somelar, P., Mahaney, W.C., Kirs, J., Vircava, I., Kirsimäe, K., 2014. Late Neoproterozoic Baltic paleosol: intense weathering at high latitude? Geology, 42: 323-326.
Lorentzen, S., Augustsson, C., Nystuen, J.P., Berndt, J., Jahren, J., Schovsbo, N.H., 2018. Provenance and sedimentary processes controlling the formation of lower Cambrian quartz arenite along the southwestern margin of Baltica. Sedimentary Geology, 375: 203-217.

Lundmark, A.M., Lamminen, J., 2016. The provenance and setting of the Mesoproterozoic Dala Sandstone, western Sweden, and paleogeographic implications for southwestern Fennoscandia. Precambrian Research, 275: 197-208.

Matyja, H., 2006. Stratigraphy and facies development of Devonian and Carboniferous deposits in the Pomeranian Basin and in the western part of the Baltic Basin and palaeogeography of the northern TESZ during Late Palaeozoic times (in Polish with English summary). Prace Państwowego Instytutu Geologicznego, 186: 79-122.

Meshcherskii, A.A., Kharin, G.S., Chegesov, V.K., 2003. Precambrian weathering crust of the crystalline basement in the Kaliningrad District. Lithology and Mineral Resources, 38: 48-54.

Migoń, P., Lidmar-Bergström, K., 2002. Deep weathering through time in central and northwestern Europe: problems of dating and interpretation of geological record. Catena, 49: 25-40.

Modliński, Z., Jacyna, J., Kanev, S., Khubldikoy, A., Laskova, L., Laskovas, J., Lendzion, K., Mikazane, I., Pomeranceva, R., 1999. Palaeotectonic evolution of the Baltic Syneclise during the Early Palaeozoic as documented by palaeo thickness maps. Geological Quarterly, 43 (3): 285-296.

Molenaar, N., Vaznytè, J., Šliaupa, S., 2019. Aridisols in the Southern Permian Basin of Lithuania: a key to understanding clay cement distribution. International Journal of Earth Sciences, 108: 2391-2406.

Motuza, G., Čečys, A., Kotov, A.B., Salnikova, E.B., 2006. The Žemaičiu Naumiestis granitoids: new evidences for Mesoproterozoic magmatism in Western Lithuania. GFF, 128: 243-254.

Motuza, G., Motuza, V., Salnikova, E., Kotov, A., 2008. Extensive charnockitic-granitic magmatism in the crystalline crust of West Lithuania. Geologija (Vilnius), 50: 1-16.

Nenonen, K., Johansson, P., Sallasmaa, O., Sarala, P., Palmu, J.P., 2018. The inselberg landscape in Finnish Lapland: a morphological study based on the LiDAR data interpretation. Bulletin of the Geological Society of Finland, 90: 239-256.

Nielsen, A.T., Ahlberg, P., 2019. The Miaolingian, a new name for the 'Middle' Cambrian (Cambrian Series 3): identification of lower and upper boundaries in Baltoscandia. GFF, 141: 162-173.

Nielsen, A.T., Schovsbo, N.H., 2011. The Lower Cambrian of Scandinavia: depositional environment, sequence stratigraphy and palaeogeography. Earth-Science Reviews, 107: 207-310.

Nielsen, A.T., Schovsbo, N.H., 2015. The regressive Early-Mid Cambrian 'Hawke Bay Event' in Baltoscandia: epeirogenic uplift in concert with eustasy. Earth-Science Reviews, 151: 288-350.

Paškevičius, J., 1997. The Geology of the Baltic Republics. Geological Survey of Lithuania, Vilnius.

Paszkowski, M., Budzyń, B., Mazur, S., Slama, J., Shumlyanskyy, L., Środoń, J., Dhuime, B., Kędzior, A., Liivamägi, S., Pisarzowska, A., 2019. Detrital zircon U-Pb and $\mathrm{Hf}$ constraints on provenance and timing of deposition of the Mesoproterozoic to Cambrian sedimentary cover of the East European Craton, Belarus. Precambrian Research, 331: 105352.

Peters, S.E., Gaines, R.R., 2012. Formation of the 'Great Unconformity' as a trigger for the Cambrian explosion. Nature, 484: 363-366.

Phillips, J.D., 2002. Erosion, isostatic response, and the missing peneplains. Geomorphology, 45: 225-241.

Poprawa, P., 2019. Geological setting and Ediacaran - Palaeozoic evolution of the western slope of the East European Craton and adjacent regions. Annales Societatis Geologorum Poloniae, 89: 347-380.

Poprawa, P., Šliaupa, S., Stephenson, R., Lazauskienè, J., 1999. Late Vendian-Early Palćozoic tectonic evolution of the Baltic 
Basin: regional tectonic implications from subsidence analysis. Tectonophysics, 314: 219-239.

Poprawa, P., Krzemińska, E., Pacześna, J., Amstrong, R., 2020 Geochronology of the Volyn volcanic complex at the western slope of the East European Craton - relevance to the Neoproterozoic rifting and the break-up of Rodinia/Pannotia. Precambrian Research, 346: 105817.

Sivhed, U., Erlström, M., Bojesen-Koefoed, J.A., Löfgren, A. 2004. Upper Ordovician carbonate mounds on Gotland, central Baltic Sea: distribution, composition and reservoir characteristics. Journal of Petroleum Geology, 27: 115-140.

Soesoo, A., Puura, V., Kirs, J., Petersell, V., Niin, M., All, T., 2004 Outlines of the Precambrian basement of Estonia. Proceedings of the Estonian Academy of Sciences. Geology, 53: 149-164.

Sopher, D., Juhlin, C., 2013. Processing and interpretation of vintage 2D marine seismic data from the outer Hanö Bay area, Baltic Sea. Journal of Applied Geophysics, 95: 1-15.

Sopher, D., Erlström, M., Bell, N., Juhlin, C., 2016. The structure and stratigraphy of the sedimentary succession in the Swedish sector of the Baltic Basin: New insights from vintage 2D marine seismic data. Tectonophysics, 676: 90-111.

Stirpeika, A., 1999. Tectonic evolution of the Baltic Syneclise and local structures in the South Baltic region with respect to their petroleum potential. Geological Survey of Lithuania, Vilnius.

Šliaupa, S., Hoth, P., 2011. Geological evolution and resources of the Baltic Sea area from the Precambrian to the Quaternary. In:
The Baltic Sea Basin. Central and Eastern European Development Studies (CEEDES) XIII (eds. J. Harff, S., Björck, P. Hoth). Springer-Verlag, Berlin, Heidelberg.

Thybo, H., 2000. Crustal structure and tectonic evolution of the Tornquist Fan region as revealed by geophysical methods. Bulletin of the Geological Society of Denmark, 46: 145-160.

Tuuling, I., Flodén, T., 2000. Late Ordovician carbonate buildups and erosional features northeast of Gotland, northern Baltic Sea. GFF, 122: 237-249.

Tuuling, I., Flodén, T., 2007. The Ordovician-Silurian boundary beds between Saaremaa and Gotland, Baltic Sea, based on high resolution seismic data. Geological Quarterly, 51 (3): 217-229.

Tuuling, I., Flodén, T., 2011. Seismic stratigraphy, architecture and outcrop pattern of the Wenlock-Priidoli sequence offshore Saaremaa, Baltic Sea. Marine Geology, 281: 14-26.

Tuuling, I., Flodén, T., 2013. Silurian reefs off Saaremaa and their extension towards Gotland, central Baltic Sea. Geological Magazine, 150: 923-936.

Vasilyev, V.A., 1969. Ancient weathering crusts of the crystalline basement in the Southern Baltic region (in Russian). Mintis, Vilnius.

VO Tekhnoeksport, 1985. Summarized maps of the Curonian part of the Baltic Sea, scale 1:100000. Graphical appendices (in Russian). Moscow. 